\title{
THE DEPICTION OF HOMOSEXUALITY IN AMERICAN MOVIES
}

\author{
Rudy \\ ${ }^{1}$ Faculty of Pedagogy and Education Universitas Prima Indonesia (UNPRI) Medan \\ Email: rudolphlim@yahoo.com
}

\begin{abstract}
This study focuses on the depiction of homosexuality in American films. It is intended to identify the images of gays depicted in American films as well as the characteristics of American gay movies. It incorporates library research by applying an analytical descriptive approach in analyzing the data. The symbol and reflective theory is used to analyze 18 American movies and 14 gay films from other countries in the early 2000s. It shows that gay films can attract audiences by describing gays as the objects for laughs; gays revealing their sexual identities; sexual scenes of gays; masculine gay men; and violence in gay life. They appear in genres like drama, comedy, romance, detective, western, and horror/mystery with two images of gay people shown in American gay movies; they are the portrait of gays as a minority and the pessimism. However, it also shows that some American gay films picture good gay life, happy gay couples, gay marriage, etc.
\end{abstract}

Keywords: homosexuality, depiction of homosexuality, American gay movies

\section{INTRODUCTION}

Society is dynamic and it surely changes from time to time. There are more complexity and variations of ways of life, life styles including principles, perceptions, concepts, and points of view, etc. It is true to say social facts show that there are phenomena in a multicultural country such as the United States of America. One of the significant social phenomenon is the issue of homosexuality.

In daily life, there are people who have different sexual orientations such as gays, lesbians and bisexuals. Homosexuals are almost always described as a deviation or abnormality. This indeed causes a serious gap between homosexual people (gay) and heterosexual people (mostly known as 'straight'). It is unavoidable that homosexuality has become a very controversial subject in almost every country. They are everywhere over the world, even though their population is not as big as heterosexuals. Society as the most important aspect in humans' lives certainly gives impacts to homosexuals. As a part of society, gay people cannot be excluded from the social life. However, there is not much to explain about them, since their sexual orientation has definitely created a negative image to the concept of homosexuality that most people have.

There have been many opinions or arguments on their way of life. However, most of these homosexuals hide themselves and secretly practice homosexuality, whereas some of them are trying to face the truth that they are different and fight for their rights to live in their own ways. But there are certainly many people who do not know about the life of homosexuals. Among the homosexuals, gays and lesbians are the common ones that are widely known. Gays and lesbians are now trying very hard to fight for their civil rights in order to show that they deserve happy lives, though they are different in sexual orientation.

Many people consider that gay culture has become a phenomenon in the social life. However, not many people respond in the same way. Even if gay people are gathered in a community, many of them do not obviously expose themselves. For 
this reason, people seldom notice gay life. In other words, people seem to assume that all people are heterosexuals because it is implied. This can be understood because mainstream culture has not perceived that being gay is acceptable, therefore, gay men frequently hide themselves or avoid being known as gay (Anderson, 2002: 873; Marcus, 2005:38).

Homosexuality is not something that many people want to talk about. It is because society knows very little about it or they do not know it at all (Oetomo, 2001:43). Besides the stigma attached to gay men as an abnormality and a deviation as mentioned previously, being gay is also perceived as a crime and the worst is that it is sinful (Davies and Rentzel, 1993: 189). Some people who view this from a different angle will perhaps consider homosexuality as a part of social complexity. But these days, there have been many people start talking about gay people. Gay people or heterosexuals (straight) even write about gay life in literary works. Gay life has also become widely known, since there are many popular literary works such as films, novels, short stories, etc. that depict homosexuality. As a part of popular literature, films/movies certainly play a very important role.

First of all, it is essential to view some relevant concepts related to the study. In regard to the social conditions of gay people depicted in the films, a basic understanding of queer theory with the basic understanding shows that sexuality is not natural, but rather, is discursively constructed (Sullivan, 2003:1). In order to understand the definition of homosexuals, some perspectives and concepts have been included in this study. Historically, it is reported that the word 'homosexual' was coined by Karl-Maria Kertbeny in 1869 by putting forward the view that homosexuality was inborn and unchangeable and showing that many of the powerful heroes were homosexual. The use of the term was then popularized by Richard von KraffEbing in his influential book Psychopathia Sexualis in 1886 (Kadir, 2007:71).

In society, the word 'homosexuals' is frequently replaced by the term 'gays' (Marcus, 2005: 3). This term is widely used to refer to male homosexuals, whereas the term 'lesbian' is used to define a woman who is sexually attracted to the same sex. In connection to sexual pluralism, some experts convey that homosexuality is a sexual preference for one's own sex. Some people are pure homosexual; others may engage in the practice of homosexuality only in certain situations, such as imprisonment; while still others have both homosexual and heterosexual experiences. Both males and females can be homosexuals (Julian and Kornblum, 1986:84). Such a condition can show that homosexuality exists in every society. And it has been a phenomenon in social life. The term 'homosexuality' is widely used for a person who practices homosexuality and is called a homosexual. It can be said as a person, a man or a woman, who is sexually attracted to people of the same sex. And to this day, this term is used as the opposite of 'heterosexual'. The concept is similar to Sullivan's idea in the book A Critical Introduction to Queer Theory defining "homosexual" as same-sex practices (2003:2). Some experts such as Hirschfeld and Ulrichs even develop a notion of a third sex, or sexual pluralism (Sullivan, 2003: 11-12). From the statement above, it can be understood that sexuality is various.

Since homosexuality has become a particular social issue, there have been many references trying to define the word homosexuality. In general, the word 'homosexuality' is used in certain fields only. In other word this term is not widely used. It is more often used in the medical world, psychology, or other writings/reports. The term 'homosexuality' carries a meaning that can bring an unpleasant feeling particularly to certain people who do not fully understand the exact definition of it.

There are many movies depicting the life of homosexuals in society. In fact, more and more popular gay movies appear in the year 2000's, particularly in the USA. For that reason, gay life pictured in American films is very reasonable to be discussed in the study, since the gay community is a part of social complexity. Many useful and fascinating things can be explored in gay films. Thus, it is very interesting to present the gay life portrayed in movies. Gay movies have become more well-known since the 1990's. American gay movies keep on developing from time to time. More gay films offer different types of stories. There have been comedy, romantic scenes, horror, detectives, and violence in American gay movies, 
particularly in the 2000's. Some of the gay movies have even won some Academy Awards. This has proven that gay movies have certain values. Additionally, as one of the cultural agents mentioned by Kasiyarno (2014: 17), it can tell that movies are produced to offer a chance for people to feel and taste and thus to satisfy them. For this reason, gay films are necessarily essential to be studied.

Movies that are concerned with the life of homosexuals has definitely become a source of research, thus there are undoubtedly many things to be observed. In relation to that, there are several objectives based on the analysis. First is to understand the existence of gays in social life; to find out how American people perceive gay movies and finally to identify the characteristics of American gay films and the image of gays portrayed in the films. So, in this study, films become the media in exploring gay life. Movies/ films as cultural products carry cultural beliefs. They expresse complex feelings, values, and ideas through symbols and myths (Cawelti, 1976: 27). In this way, this study intendes to explain about the reflections and the pictures of gay life shown in films. As has been mentioned previously, films as cultural products are famous all over the world. It has become a popular culture. America, for instance, shows that its popular culture has expressed itself through almost every medium including films, music, and sports. Movies have never lost their original character as a medium of popular culture (Sklar, 1975:5).

There is no doubt that film can be one of the favorite choices for many people to spend their leisure. Even if it is in a different language, the message will be conveyed by the visual storytelling (Staples, 1973:428). The condition above proves that the roles of TV and movies have become very important in recent life. These electronic media certainly give impact toward social life in many ways. Electronic media has become very popular and influential since the twentieth century. They give definite idea to daily life, the role of men and women inside and outside the home, and the shaping of personal and national identity (Boddy, 2004:4). Themes and characters shown in films can portray social facts.

Based on the explanation above, there are certainly basic particular aspects that can be observed to give a path to the analysis served in the present study. The objectives of the study is to figure out the characteristics and images of gays depicted in American gay-themed films which pave a way to understand the existence of gay in the society.

This is an interdisciplinary study which includes historical and sociological aspects in studying gay films. Since homosexuality has been something special to be shown in films as the media, the primary data of the study are 15 American gay movies: Adam \& Steve (2004), A Cool Day in Hell (2005), Another Gay Movie (2006), Boy Culture (2006), Brokeback Mountain (2005), Edge of Seventeen (1998), Ethan Mao (2004), I Now Pronounce You Chuck and Larry (2007), Latter Days (2003), Luster (2001), Philadelphia (1993), Poster Boy (2004), Third Man Out (2007), Wedding Wars (2007) and 200 American (2003) as the primary data and some additional data taken from two American gay-themed television series: Dante's Cove (2005) and Queer as Folk (2000) and 12 gay-themed movies from other countries such as A Big Bang Love: Juvenile (2006/Japan), Touch of Pink (2003/ The UK), Arisan (2004/ Indonesia), Bear Cub (2004/ Spain), Coklat Stroberi (2001/ Indonesia), Cut Sleeve Boys (2006/ Indonesia), Eleven Men Out (2007/ Iceland), Eternal Summer (2006/ Taiwan), His Secret Life (2002/ Italy), Just a Question of Love (2000/ France), Metrosexual (2007/ Thailand), and No Regret (2006/ South of Korea). Most of the films are obtainable in the market and available as DVDs, so that data observation through video watching can be more effective. American gay movies have been the focus because the present study concentrates on the portraits of gay men in American films.

The method of analysis is done by applying analytical descriptive qualitative technique. According to Hariwijaya and Djaelani (2004:39), descriptive research is intended to search as much information as possible from a certain phenomenon. Thus, during the research, more data on the topic are needed to achieve satisfying outcomes. This study mainly incorporates library research. This study uses gay movies as the source to show the life of gay people. Throughout the analysis of the films by using the symbol and 
reflective theory, gay life shown in the movies can be explored in order to relate to society. In reflective theory, the meaning lies in the object, person, thoughts, experience in the reality while language has a role as a reflection (Hall, 1997:24). Some additional data taken from relevant references are necessarily needed to explain the development of gays in society showing their ways of expressing the sexual identity and people's perceptions of homosexuality in films (as mentioned above).

\section{DISCUSSION}

Nowadays, gay characters have become more visible. In addition, gay-themed films are frequently seen in Hollywood. However, it seems that gay films do not obtain good responses from the society due to the stereotype of gay people. There are some people who dislike and oppose gay life pictured in the films. Therefore, this research can show that gay movies are also important to be observed and studied. Moreover, the study of gay films can definitely point out that there are several interesting points found in American gay movies discussed here.

From the observation of the gay movies done during the research, it can be identified that there are some aspects used in the films in order to attract the audience. It is important to note that a film must be able to be an effective means of entertainment. For this reason, American gay films have fulfilled several essential features to draw the spectators' attention. There are some pictures of gays that can actually become important points to be included in gay films. Those features are believed to be very important in popularizing the gay movies. The analysis of this study also shows some images of gays depicted in the films.

\section{GAY FILM AS AN ATTRACTION}

From the data observation and analysis, it is clear that there are some images of gay characters depicted in the films that can reflect as an attraction. As defined by Oxford Advanced Learner's Dictionary (2000: 67), one of the definitions of 'attraction' is "a feature, quality or person that makes something seem interesting and enjoyable, and worth having or doing".

Gay characters are often used for laughs. There are amusing gay scenes which are always presented in almost all American gay films. They are the scenes showing the ways gays attract other gay men, the gossip and jokes they tell to each other, the way they communicate and express their feelings, the way they dress up, the effeminate way they behave, etc. In addition, gay love stories are frequently associated with fun and laughs, too. Those scenes are intended to amuse the audience, such as those shown in American gay movies, like Adam and Steve (2004), Another Gay Movie (2006), Wedding Wars (2007), The Broken Hearts Club (2000), etc. This kind of stigma has been seen in the social life for such a long time. Benshoff and Griffin (2006: 24) point out:

By the 1920s, a stereotypical image of male homosexuality was prevalent both in the cinema and in real life: the pansy. Pansy was a term used colloquially to describe a certain type of queer man- a flowery, fussy, effeminate soul given to limp wrists and mincing steps.

"Effeminate" behavior of gay characters seems to be a stereotype (Wlodarz, 2009: 89). It becomes the general signature of gay people, therefore, the "sissies" are considered amusing. Moreover, they are often shown in a comedy genre. This shows that people would like to enjoy something hilarious to release their stress and burdens. The condition like this can tell that it is possible that not many people want to see the gay life in movies for certain reasons. So, in order to make the movie alive, many amusing acts are inserted. But on the other side, there are spectators or gay people who desire to see how the gay relationship works.

Gays declaring their sexual identities in films can actually become an interesting point. This is shown in Poster Boy (2004), Latter Days (2003), Wedding Wars (2007). Many American gay movies put forward scenes where the gay character declares his sexual identity to the straight people around them such as parents, friends, etc. There is a tendency in some gay people to be able to express their sexual identity, to show their feelings to their partners without being afraid, while many gay people refuse to show their homosexuality because they do not want to be identified as a minority (Julian and Kornblum, 1986:88). 
It cannot be assumed that all people hate gay people. In fact there are also people who definitely support gay rights, because there are more homosexuals who have come out to declare their sexual preference. In relation to this, Wagner and Voorhis give the emphasis that nowadays more gays are not trying to hide themselves any longer. They are quite open to their families, companies, etc. This situation is reflected in American gay films (Kerger et. al., 2003:48). Thus, Many American gay movies depict scenes where the gay character declares his sexual identity. Something unexpected as shown in Poster Boy (2004) can be very fascinating to the audience, especially the gay audience. Identity became very important to gay people because identity is culturally generated by strength in order to show the existence. (Peele, 2007: 7)

Some people who can understand gay life will probably long for a more positive scene as pictured in Philadelphia (1993).It is because this movie touches on the subjects such as homosexuality and heterosexuality, family, life, work and death, thus people should not think that this is a preachy film. It is a reflection of how gay people live in the society and the obstructions they have to face. Some American gay films such as Wedding Wars (2007), Another Gay movies (2006), Adam and Steve (2004). also depict parents accepting their sons' homosexuality. A gay movie from The United Kingdom such as Touch of Pink (2003) also proudly shows an understanding mother showing love and caring for to her gay son. People can see how courageously the gays can express themselves particularly in showing their sexual identity to the majority. From the condition above it can be inferred that homosexuality to gay people is their identity and they want people to recognize and respect it.

Gay films also show erotic scenes in gay life. The previous explanation has presented that some gay characters are often portrayed as a group of lowly panties wearing men with makeup who always desire sex. They are also pictured as flirtatious, sexy, and naughty drag queens and people who have no hopes and future, rejected by society. When people hear the word 'gay', they will have negative images of it. Some of them say that it is identical to porn films; some believe that gay scenes frequently expose something immoral such as nudity, promiscuity, orgies, etc. Such a condition gives the society a perception that gay is a symbol of promiscuity. This statement is firmly labeled in gay life because of the stereotype constructed in society.

Marcus (2005: 129) explains "If you believe what some people say about gay men, you would think that all gay men have had a thousand or more sexual partners by the time they're thirty." From the idea above, it seems that there is a perception showing that people assume that gay people have more sex, therefore erotic scenes are shown in gay movies. From the films observed in the study, there are indeed scenes showing eroticism. The movies depict the image of sexual intimacy. In other words, it can say that gay culture seems to be identical with the blatant eroticism among gay men. The negative label connected to the stereotypes of gays tends to be erotic sophistication. This is because many people simply relate gay life to promiscuity. This can reflect how the gay community is marked as a group of weird people who live for ridiculous fun and strange sex activities. The picture of sexuality can also be the part that some people enjoy. In general, people believe that gay scenes in movies expose sexual acts rather than affection, love or morality. Therefore, Waugh (1995: 314) argues that the idea of gay life being identical with pornography seems to be the stigma in gay culture. Spectators who are interested in watching gay films can be those who are curious about the gay sexual life. This can show that people still think that gay movies cannot be expected to depict good values or moral teaching.

The depictions of a gay couple's intimacy and sex life shown in the films can also seems to be the attraction. Being generally categorized as sexual deviation in society, same-sex erotic scenes shown in gay films can somehow be related to the idea of sexual identity particularly in the era of modernity (Reumann, 2005: 216). Series like Queer As Folk (2000) and Dante's Cove (2005) obviously expose a lot of sex scenes. With regard to sexual scenes pictured in gay films, people believe that gay sexuality might be a kind of fantasy. However, it mostly evokes a negative response. Porfido (2007: 65) explains "Surely Queer as Folk's candid and joyful images of sex and lust were a defiant challenge to a representational 
regime in which homosexual pleasures are either completely ignored or associated to disease, contagion and death." Therefore, from the situation mentioned above, gay sexuality is still perceived as a "negative" image.

In relation to the point about attraction shown in American gay movies, it can be related to the presence of 'fantasy'. People tend to seek for what they desire. Fantasy is considered as perfection. And it shows that art enables human beings to take part (Iser, 1993:171). So, it can be said that most of the images shown in films are actually for the sake of fantasizing. However, from observation, there is a change found in the depiction of gay characters in the movies. This modification is seen as a shift from the conventional perception of homosexuality to a modern picture of gay men. It is "masculinity". Masculine gays also become the central of attraction in many gay movies discussed in this study. Carroll (2003: 218) mentions:

By the 1970s, gay masculinities had become highly varied, ranging from the 'macho men' (as exemplified by the pop group The Village People) who incorporated, in exaggerated form, traditionally masculine characteristics to the drag queens who continued to seek male identities that included characteristics traditionally considered feminine.

Many gay people appear in the films are described as masculine, macho and good-looking men such as the two masculine cowboys in Brokeback Mountain (2004), the straightlooking detective Third Men Out (2007), and a masculine male hustler in 200 American (2003). The "masculinity" pictured in gay people on the movies has become more obvious in the reality. Masculinity in gay people seems to play an important role in their life. In relation to that Reddy (1998: 65) explains "One possible interpretation is that gay masculinity hints at a collection of ideas, attitudes and assumptions which culturally determine the way gay men view themselves as men". After all, gay men are still perceived as men even if they have a different sexual orientation from the straight men.

In reality, there is a general perception that having a muscular body and a macho behavior can be the symbol of masculinity. Filiault (2010: 68) describes that "Frequently, the body was discussed as being a marker of a man's status as a man. In particular, there was a frequent association between muscularity, physical size, and masculinity." Becker (2009: 94) explains that masculine gay characters also started to appear in television series in the 1970s. This can tell that masculinity is universal. There are gay movies from other countries that also picture masculinity in gay characters. Gay films from Asian countries such as Metrosexual (2007) from Thailand, Eternal Summer (2006) from Taiwan, and No Regret (2006) from South of Korea. picture masculinity in gay characters. And this can attract both gay people and non-gay people to many people to watch. An Indonesian gay movie, Arisan (2004), for instance, stars by a handsome actor, Tora Sudiro who acts as a gay in the film is eye-catching and good looking. The gay character he plays is "masculine". His role as a gay character in the film Arisan (2004) was nominated and won an award in Indonesian Films Festival 2004 for the best actor category. This phenomenon shows the change of general perception of gay people as feminine males in gay films.

Consequently, there must be an expectation behind masculine gay men in movies. It can be understood that the purpose of picturing gay in a masculine way can also attract a female audience. Nowadays, the spectators expect to see the capability of the characters in the films to attract both men and women (DeAngelis, 2000: 184). Corresponding to the masculinity portrayed in gay people, it is believed that the notion of a gay community becoming more visible to mainstream culture, many gay males begin to distance themselves from a stereotypical association to femininity (DeAngelis, 2000:132).

Another frequent portrayal shown in gay films is violence. This feature is intended to give the sense of challenge to the spectators, for instance, in Ethan Mao (2004) and Third Men Out (2007). Besides, gay movies, American gay television series such as Queer as Folk (2000) and Dante's Cove (2005) also portray violence in gay life. There is a lot violence in gay life that has been depicted in many American gay films. This situation shows that gay people who experience extreme anxiety 
for their independence and civil rights tend to be depressed. If this condition worsens, more serious violence will occur. It is connected to the feeling of uneasiness, uncertainty, fear, and agitation which can cause severe stress (Oppenheim, 1994:65). And it also has a strong connection to anger and hatred which is also found in some gay movies discussed in this study. It can show that gay people will have chances to experience or do violence, because of their different sexual identity. This is, however, a kind stereotype attached to gay people.

There are several types of violence reflected in the gay movies discussed in this study. It includes the violence toward the gay people such as "gay bashing". Tully (2000: 175) emphasizes that "Lesbians and gays are at risk of being the victim of a hate crime or the victim of domestic violence simply because of their perceived or actual sexual orientation." In this situation, gay people in reality are considered weak since they are likely to be dominated in the straight community. Therefore, they are pushed to defend themselves.

The discrimination experienced by gay people is believed to be the most terrible suffering and burden. This idea is supported by Hite's report conveying that most men who have practiced same-sex activities find it hard to deal with society (Hite, 1981:827). The fact that they are oppressed has forced gay people to be involved in violence against straight men as an act of revenge.

However, the scenes of violence as shown in gay films can be an attraction because there is a possibility that the audience who come to see gay movies certainly will have some expectations on the most serious trouble and challenges in gay life. In relation to that, a famous American filmmaker, Sydney Pollack, believes that movies that can challenge and provoke us or even make us angry are actually good movies. Such films usually show ideas that are opposite from what people think (Petracca and Sorapure, 2004:528). Consequently, that may evoke various kinds of emotions from the audience. It is true that many spectators can be interested in violent actions. People who see gay life as a source of troubles will certainly be thrilled when they see acts of violence and they will also get satisfaction for they are entertained by something challenging.

The depiction of straight people engaged in acts of violence are common, but when gays face troubles, the audience may wonder how such people can overcome their difficulties and survive in social life. Violence depicted in gay films can actually show that gay life is described as a harmful life. However, the films which present the violence in gay life are interesting. It shows the different types of conflicts in the gay community to satisfy the audience.

\section{THE IMAGE OF HOMOSEXUALITY AS A MINORITY IN FILMS}

In society, gay men are associated with the minority. Indeed, this is also reflected in films. Most of these gay people are often treated improperly if their sexual identity is known. Thus, many gays still disguise themselves. This is because their sexual preference is not fully accepted by their social community. Therefore, they usually gather with their own gay friends or other gay people to socialize.

The social condition of gay people as a minority becomes the main issue in many gay films. Hooker believes that homosexuals are a deviant group in society because their experience is rejected by the larger society and not because of anything inherent to homosexuality (Julian and Kornblum, 1986:86; Quinn, 2008: 207). This condition certainly creates a gap between majority and minority, in this case, heterosexuals and homosexuals. And it will certainly lead to the practice of discrimination toward minorities.

Many gay men have very often been separated from their blood families, thus, they seem to approach friendship with a certain self-conscious determination (Julian and Kornblum, 1986: 7-8). In addition, regarding the discrimination toward gay people, some experts argue that gay men have historically created families. For some, it is a question of replacing traditional "blood" families that have denied or expelled them. For others, it is simply a natural evolution of maturity. As they seek to define their lives on their own terms, they gather a chosen network of people to nurture and care for them. People need friends, so do gay people (Preston, 1995: 7-8). In reality, it is true to say that there is a strong solidarity among people who are discriminated. This was also common amongst in the African-American people before and during the 
Civil Rights Movement. The portrait of solidarity amongst gays as the minority continuously gives impact to American gay films. And some of these gay movies, Philadelphia (1993) for instance, have been nominated for Academy Awards, the highest achievement in the American film industry. This Academy Award winning movie shows the virtue of solidarity and friendship. The straight black character decided to help a gay attorney with HV to fight in court. This shows that both AfricanAmerican and gay people have experienced discrimination and prejudice. For that reason, they both share the same pain.

Thus, solidarity is an important aspect in minorities. As a minority, gay people need strength and support one another in order to struggle and survive in the social life which is dominated by heterosexuals. They gain support from their gay friends and some people who are willing to understand and accept them. This is because not many people can understand them, even their own families. Gottlieb (2008: 4) explains: "For gay men, however, friendship has never been thought of as secondary. Rather, those relationships have always been safe havens, places where we can be understood, feel valued, and experience acceptance and love." From that point of view, it is clear that friendship for gay people is meaningful.

Besides the solidarity among gays and lesbians, some American gay films also show a very close relationship between gay people and straight people. This proves that there are heterosexuals that can tolerate, understand and accept gay people. This is what gay people need in their social life. Such a condition is depicted in Adam and Steve (2004). It portrays a friendship between gays and heterosexuals. So, from the data observation, it shows that many of the gay films depict a strong relationship among gay friends. The condition above shows that the friendships among gay people lead to the solidarity that is useful to gain strength to survive in the society with heterosexuals as the majority. Besides, other minority groups who experienced discrimination experience can also show sympathy toward gay people.

\section{THE PESSIMISM IN GAY LIFE SHOWN IN FILMS}

Gay films almost always portray gay life in a pessimistic way. It is necessary to identify why pessimism is frequently included in gay-themed movies. Pessimism in gay stories has probably been a kind of common thing. From around 1930's, there were many novels and films in which gays are constructed as sad and twisted creature preserve desires would inevitably lead to a tragic down fall (Sullivan, 2003:18). This means that same sex relationships are the stuff of tragic plots and hidden identities, no matter how frail or loose it might be. Such desire tends to enable and complicate many aspects of their lives (Flora and Mackethan, 2002:291). This condition is shown in Brokeback Mountain (2005), Philadelphia (1993), Luster (2001), etc.

The pessimism found in gay-themed movies centers around love, family, jobs, and environment. Edge of Seventeen (1998), for instance, portrays a despairing gay life. The main character, Eric, is a teenager searching for his sexual identity and he feels confused. He is tortured for he cannot find a man who really wants a relationship. He is cheated on his first love, Rod. He then has sex with other men. His relationship with his girlfriend Maggie does not work at all. He then has a quarrel with his family. There have been many American gay movies that portray the torment of gay life, troubles in love, tragic endings, etc.

It is believed that literary works that portray homosexuality tend to end in a tragedy. Same sex relationship is the stuff of tragic plots and hidden identities, no matter how frail or weak it might be. Such desire tends to enable and complicate (Flora and Mackethan, 2002:291). The tragic ending of the gay-themed movies obviously becomes the symbol of pessimism in gay life. Negative images such as male prostitutes, hustlers, sex addicts, and annoying, flamboyant, effeminate men are continuously used to describe gay life. These unpleasant depictions show pessimism in gay life. Such images are found in American gay movies being discussed in the study such as Adam \& Steve (2004), Another Gay Movie (2006), Boy Culture (2006), Latter Days (2003), and 200 American (2003). Gay movies from other countries also portray pessimism in gay community. 
Pessimistic conditions are also depicted in gay movies from other foreign countries such as A Big Bang Love: Juvenile (2006), Cut Sleeve Boys (2006) The Bubble (2006), and His Secret Life (2001). They usually depict loneliness, confusion, fright, and death instead of loving and hopeful gay couples living together. Asian gay films for instance, show the unhappy life of gay people in Asia. A Korean gay film for instance, No Regret (2007) portrays torment in love. Loneliness as one of the types of pessimism in gay life is reflected in the Taiwanese movie Eternal Summer (2007). The observation shows that gay movies discussed in this study describe gay life with a lot of problems and obstructions in pursuing their love.

Another pessimistic point is drug abuse among gay people pictured in gay films. Most gays use drugs for certain reasons such as fun, escapism, etc. That can be seen in gay-themed movies such as Luster (2001), Ethan Mao (2004) and even in some of the American television series such as Queer as Folk (2000) and Dante's Cove (2005). The picture of gays using drugs is also found in some foreign gay movies such as Bear Cub (2004) and Out Sleeve Boys (2006). From the drug scenes above, the spectator will notice that the drug experience that gay men have are not much different from straight men do. It can show that people actually live in the same way. So, the point that can be emphasized here is that, apart from the stereotype of gay people in the society, overall the depictions of gay men in movies are not much different from other heterosexual characters. In other words, this can indicate that both heterosexual and homosexual people have so much in common, particularly in American films. This can be compared to the idea pointed out by Butler (1990: 51) "It is unclear what is the 'exaggerated' form of heterosexuality the homosexual man is alleged to display, but the phenomenon under notice here might simply be that gay men simply may not look much different from their heterosexual counterparts."

However, gay-themed movies observed in the study do not always show pessimism. Some of them also show good images. American gay films also picture happy gay couples with more affection, love, expectations and happy endings, such as The Broken Hearts Club (2000), Third Man Out (2007), Adam and Steve (2004), Latter
Days (2003), Another Gay Movie (2006), Wedding Wars (2007), etc. and those positive pictures also appear in Queer as Folk (2000) and Dante's Cove (2005). Foreign gay-themed movies such as Touch of Pink (2003) from the UK, 3 Guys, 1 Girl, 2 Weddings (2004) from France, Bear Cub (2004) from Spain, as well as His Secret Life (2002) from Italy portraying happy-ending gay love couples.

\section{CONCLUSIONS}

Based on the analysis, this study has revealed some conclusions about the depiction of homosexuality in America films. First of all, it can tell that the reality of gay people being discriminated is pictured in gay movies. Gay people were not fully accepted in American society in the early 2000s. For that reason, prejudice toward gay men was widely shown in American society at the beginning of the 2000s.

Second, it can be concluded that people enjoy gay films for the purpose of entertainment. The films include many interesting aspects to draw the audience's attention. Therefore, many of the gay-themed movies are comical and amusing. Audiences will tend to see gay people on the movies as funny characters with their effeminate behavior. However, many of the gay-themed movies observed in the study show that gay characters are also depicted as masculine and good-looking men as well as promiscuous.

Third, apart from the stigma constructed in society about homosexuality, the study shows that gay films are not always identical with or assumed to be immoral, negative depictions or pornography. In fact, gay characters can appear in genres such as drama, comedy, romance, horror, detective, etc. that are also similar to other types of mainstream films.

From the movie observation and analysis conducted in the study, there are some images of gay people portrayed in the films. There are common images that frequently appear on gaythemed movies. 'The state of being a minority' is shown in the movies. Therefore, gay people gain support through the friendship. Another frequent image that appears in gay movies is 'pessimism' such as sad-ending love stories, discrimination, violence, the use of drugs. In fact, these two images are reflected in gay social life. However, some gay- 
themed movies also show some positive values and happy couples at the end.

\section{REFERENCES}

Anderson, E. (2002). “Openly Gay Athletes: Contesting Hegemonic Masculinity in a Homophobic Environment" in Gender and Society 16 (6): 860-877. "Attraction" (2000). Oxford Advanced Learner's Dictionary. Oxford University Press.

Benshoff, H. M. dan S. Griffin. (2006). Queer Images: A History of Gay and Lesbian Film in America. Maryland: Rowman \& Littlefield Publishers, Inc.

Boddy, W. (2004). New Media and Popular Imagination: Launching Radio, Television, and Digital Media in the United States. New York: Oxford University Press, Inc.

Butler, J. (1990). Gender Trouble: Feminism and the Subversion of Identity. New York: Routledge, Chapman \& Hall, Inc.

Carroll, B. E. (ed.). (2003). American Masculinities: A Historical Encyclopedia. London: SAGE Publications.

Cawelti. J. G. (1976). Adventure, Mystery and Romance: Formula Stories as Art and Popular Culture. Chicago: University of Chicago Press.

Davies, B and L. Rentzel (1993). New Freedom for Men \& Women: Coming Out of Homosexuality. Illinois: IVP Books.

DeAngelis, M. (2001). Gay Fandom and Crossover Stardom: James Dean, Mel Gibson, and Keanu Reeves. Durham: Duke University Press.

Flora, M. J. and L. H. Mackethan. (2002). The Companion to Southern Literature. Louisiana: Louisiana State University.

Gottlieb, A. R. (ed.). (2008). "Introduction" in On the Meaning of Friendship between Gay Men. New York: Routledge.

Hall, S. (ed.). (1997). Representation: Cultural Representations and Signifying Practices. London: Sage Publications.

Hite, S. (1981). The Hite Report on Male Sexuality. New York: Ballantine Books.

Hariwijaya, M. and B. M.Djaelani. (2004). Teknik Menulis Skripsi \& Thesis. Yogyakarta: Zenith Publiser.

Iser, Wolfgang. (1993). The Fictive and the Imaginary. Baltimore: The Johns Hopkins University Press.
Julian, J. and W. Kornblum. (1986). Social Problems. New Jersey: Prentice Hall.

Kadir, H. A. (2007). Tangan Kuasa Dalam Kelamin. Yogyakarta: ISIST Press.

Kasiyarno. (2014). “American Dream: The American Hegemonic Culture and Its Implications to the World" in Humaniora 26 (1): 13-21.

Marcus, E. (2005). Is it a Choice? Answer to the Most Frequently Asked Questions about Gay and Lesbian People. New York: HarperCollins Publishers.

Oetomo, D. (2001). Memberi Suara pada yang Bisu. Yogyakarta: Pustaka Marwa Yogyakarta.

Peele, T. (2007). "Introduction: Popular Culture, Queer Culture" in Queer Popular Culture. New York: Palgrave Macmillan.

Petracca, M. and M. Sorapure (eds). (2004). Common Culture: Reading and Writing about American Popular Culture. New Jersey: Pearson Education, Inc.

Preston, J. (ed.). (1995). Friends and Lovers: Gay Men Write About the Families they Create. New York: A Dutton Book.

Quinn, J. (2008). “On Friendship and Being Alone” in On the Meaning of Friendship between Gay Men. New York: Routledge.

Reddy, V. (1998). "Negotiating Gay Masculinities" in Agenda: Empowering Women for Gender Equity 37: 65-70.

Reumann, M.G. (2005). American Sexual Character: Sex, Gender, and National Identity in the Kinsey Report. Berkeley, Los Angeles: University of California Press.

Sklar, R. (1975). Movie-Made America: A Cultural History of American Movies. New York: Random House, Inc.

Staples, D. E. (ed.). (1974). The American Cinema. Washington D.C.: Forum Reader Series.

Sullivan, N. (2003). A Critical Introduction to Queer Theory. New York: New York University Press.

Waugh, T. (1995). "Men's Pornography" in Out in Culture: Gay, Lesbian, and Queer Essays on Popular Culture, C. K., Creekmur and A. Doty (eds). The USA: Duke University Press.

Wlodarz, J. (2009). "WWe're not all so obvious': Masculinity and Queer (in)visibility in American Network Television of the 1970s" in Queer TV, G. Davis and G. Needham (eds.). New York: Routledge. 